\title{
Das Deutsche Kollegium: Wesleyan's Teutonic Past
}

\author{
By Dr. Louis A. Haselmayer
}

This first extended account of the old German College at Mount Pleasant, Iowa is reprinted from the Fall issue of The Purple and White, Iowa Wesleyan alumni quarterly. The author, Professor of English and Chairman of Division of Humanities at Iowa Wesleyan College, has written several books of poetry, history and literary articles.

On the east block of the Iowa Wesleyan College campus stands the solitary, familiar red brick building known variously through the decades as the German Building, the Music Building or the Physics Building. Yet many students, alumni and even townspeople do not know that this building once housed an independent educational institution-Das Deutsche Kollegium-the German College which served from 1873-1909 as the backbone of German Methodism in the middlewest. June 9, 1959 completed a 50 year period since it ceased operations and now affords an appropriate time to take another look at this building to consider what was accomplished within its walls.

The German College grew out of the massive rush of German people into Iowa after the 1848 civil wars in Germany. German groups of many different religious backgrounds immigrated into Iowa and here strove to preserve their old world culture around churches which employed the mother tongue for services. By 1850 there were 7,152 Germans in Iowa, and the number continued to increase during the remainder of the nineteenth century.

This German element was especially strong in southeastern Iowa. Mennonite and Amish groups came into Davis, Lee, Washington, Keokuk, Iowa, Johnson and Buchanan counties. Some Amish groups have preserved a German-speaking tradition to the present. German Lutherans and German Roman Catholics settled in the Ft. 
Madison, Keokuk and Burlington areas, and sustained German churches until the 20th century.

German Methodists settled in the midwest in such numbers that the 1864 General Conference of the Methodist Church set up the Southwest German Conference which included six districts in Missouri, Western Illinois, Iowa and Kansas, consisting of 87 ministers and 5,308 members. German Methodist churches in Iowa were located at Burlington, Wapello, Davenport, Iowa City and Muscatine.

In 1870 the Southwest German Conference appointed a committee to consider the founding of a German College to serve the needs of this area. The idea interested Dr. John Wheeler, president of Iowa Weslevan University in Mt. Pleasant. He had previously been instrumental in creating an affiliation between a German College and Wallace University in Berea, Ohio. Dr. Wheeler suggested a similar arrangement be worked out between Iowa Wesleyan and the proposed new school to the advantage of both German Methodism and his own institution.

Negotiations continued at a meeting of the Iowa $\mathrm{Me}-$ thodist Conference in Mt. Pleasant, October 4-9, 1871, and at the Southwest German Conference in Warrenton, Missouri, March 20, 1872. At the second meeting, a committee appointed by the Board of Trustees of Iowa Wesleyan College, offered as an attraction in Mt. Pleasant a deed to five acres of land adjacent to the campus, a three-story brick building 40x60 feet and free tuition at Iowa Wesleyan for all students enrolled in the German College.

The Southwest German Conference meeting in Quincy, Illinois, September 19, 1872, accepted this offer and began a campaign for an endowment fund of $\$ 20,000$ for the German College. A Board of Trustees was elected and pledges for the endowment fund were accepted on April 20, 1873 in Muscatine, Iowa.

In the meantime, an Iowa Wesleyan committee was charged with soliciting $\$ 8,000-\$ 9,000$ for the promised 
building. Active in the fund raising was the Rev. W. R. Cole of Mt. Pleasant. The Cole Brothers firm in Mt. Pleasant made the largest single contribution. Two outside gifts of $\$ 500$ were received from James W. Yander of St. Paul, Minnesota and Col. George B. Corkhill of Washington, D. C.

Ground was broken on July 25, 1873 by Bishop Jesse P. Peck of the Methodist Conference. President Wheeler laid the corner stone, August 29, 1873. The Rev. R. Havighorst, who was to head the German College as vicepresident, gave an address.

Classes began September 22, 1873 with 24 students, though the building was not yet completed. Known officially as Das Deutsche Kollegium and popularly as the German College, it became the fourth of an eventual seven German Methodist educational institutions in the United States.

The primary aim of the German College was the theological training of German Methodist ministers to serve German speaking churches, particularly those of the Southwest German Conference. Instruction in theology and scripture was given in the German language, and the faculty was composed of qualified German Methodist ministers.

Dr. Edwin S. Havighorst, president from 1898-1908, forcibly stated this function of theological education in the Jubilee History of the St. Louis German Conference:

Die eigentliche Aufgabe der Anstalt ist, im besonderen Sinne eine deutsche theologische Schule zu sein, in welcher deutsche Prediger für das deutsche Werk herangebildet werden ...

The expansion of German Methodism in the middle west after the 1873 founding of the college was evidenced by the division of the Southwest German Conference into a St. Louis German Conference and a West German Conference by the 1878 General Conference. The four districts of the St. Louis Conference, which included the Mt. Pleasant German College, had 151 ministers and 11,365 members, double the figures of 1864. 
The six Iowa German congregations of 1864 grew to 16 . There was ample work for the German College, and by 1905 one hundred of its graduates had entered the German Methodist ministry.

The German College also offered other courses of study: a 3-year college preparatory course, a 4-year liberal arts program, music study, and later, business and normal training. These varied study courses were made possible by the connection with Iowa Wesleyan University, the interchange of faculty and free tuition transfers.

German College students attended Iowa Wesleyan classes taught in English, and Iowa Wesleyan students who wished to study German took this work in the German College. The professors of theology in the German College held rank as professors of German and German literature at Iowa Wesleyan University. This exchange of faculty was advertised and the catalogs of Iowa Wesleyan University stated that this department offered studies in German equivalent to studying the language in Germany itself.

A firm tradition of Germanic studies was established at Iowa Wesleyan which the university could not afford to provide on its own. The German College had its own library of 2,000 German books, and sponsored the Schiller and Goethe literary societies, as well as an English group, the Cicero Society.

The finances and administration of the German College remained completely independent of Iowa Wesleyan University. It had its own Board of Trustees appointed by the German Conference, engaged its own faculty, granted its own diploma, raised its own funds and recruited its own students.

Eleven ministers served as president of the institution from 1873-1909. Such a rapid turnover was no doubt the result of the Conference's policy on ministerial appointments, as well as by the low salary. The longest terms were those of the Rev. William Balcke, 1878-1885, and the Rev. Dr. Edwin S. Havighorst, 1898-1908. The fac- 
ulty consisted of the president, generally two other professors and a teacher of music. Courses in liberal arts, science and business were taught by members of the Iowa Wesleyan faculty.

The Rev. Dr. Havighorst was president during the last decade of the German College's existence in Mt. Pleasant. A graduate of the German College, Iowa Wesleyan (1887) and Boston universities, he was regarded as a leading figure in German Methodist educational circles. The faculty of his administration included the Rev. Karl Stiefel, 1895-1908; the Rev. H. G. Leist, 1903-1908, who later became a professor and dean at Iowa Wesleyan; and Miss Emilie Havighorst, 1901-1908, instructor in music.

A student house was organized in 1878. In 1901 a church was erected on the college campus to the south of the college building, at a cost of $\$ 7,000$. Regarded as completely suitable, "eine schöne, zweckentsprechende Kapelle," it served as a chapel for the German College students and a church for the German Methodist congregation of Mt. Pleasant. This congregation organized at the time of the founding of the college, for a time used the main room of the college for Sunday worship, and received pastoral care from one of the German College professors. The total value of the buildings and endowment of the German College by 1905 was estimated to be $\$ 55,000$.

The growth of the student body was relatively steady. In the 1880's and 1890's it reached 50 or 60 students per year. The last ten years of the German College saw its enrollment rise to 174 . The records of the school available in Mt. Pleasant today are somewhat generalized statistics making it difficult to determine the number of students in each of the various courses of study.

"The number of matriculated students," reported Dr. Charles J. Kennedy in the 1942 Centennial History of Iowa Wesleyan College, "probably never exceeded 50 or 60 in any one year." These figures refer only to those enrolled for a degree, and do not agree with the totals given in 
the annual catalogs of Iowa Wesleyan University. The German College Catalog was published together with the Iowa Wesleyan University Catalog from 1873 to 1880 , in which detailed lists of enrolled students reveal that they came from Iowa, Illinois, Missouri, Nebraska and Kansas, though the majority were from southeastern Iowa. Graduates became ministers, missionaries, teachers, medical men, lawyers and businessmen.

German college students, especially those in liberal arts, mingled freely with Iowa Wesleyan students, joining their organizations and activities. The editor of the 1909 Croaker, Iowa Wesleyan University yearbook, wrote an eloquent tribute to the vitality of leadership exercised in the university by the German College students. Student life in the German College itself revolved around its literary and debating societies.

The Goethe Society, founded in 1884, maintained a club room equipped with furniture and piano, sponsored speech and musical programs and conducted its affairs entirely in German. The Cicero Society was created in 1888 to provide similar programs in both English and German because it was felt that future ministers should be proficient in both languages. The two societies staged debates, and an intense rivalry developed between them.

The German College clearly exercised considerable influence upon German Methodism in the middlewest, and helped to keep alive a tradition of German culture in southeastern Iowa for almost half a century.

It permanently closed its doors in 1909, ending 36 years in Mt. Pleasant. The direct transfer of German culture from the mother country apparently reached its peak, and the second generation was becoming effectively Americanized. The St. Louis German Conference also supported the German Central Wesleyan University at Warrenton, Missouri, and for some years there had been talk of merging the school at Mt. Pleasant with the latter, but with each academic season they had continued to function separately. There seems to have been 
some powerful Conference influence in favor of merging the Iowa college with the Warrenton institution.

On May 27, 1908, the Mt. Pleasant Weekly News carried the first story of the possible removal of the German College from Mt. Pleasant, and its amalgamation with Central Wesleyan. The following month President Havighorst accepted the presidency of Nast Theological Seminary in Berea, Ohio, the leading German Methodist theological seminary in the United States. A professor at the German College, the Rev. H. G. Leist, was appointed to succeed him, but the future looked dim. Throughout the summer of 1908, newspaper stories speculated on the possibility of a consolidated school remaining in Mt. Pleasant. However, in September it was announced that this would be the last year of the German College.

According to the terms of the agreement in 1873 its land and buildings would revert to Iowa Wesleyan University if the German College ceased to operate in Mt. Pleasant. But there was considerable discussion about the endowment fund which had reached $\$ 30,000$. The trustees of the German College planned to transfer it to Central Wesleyan University, but the Trustees of Iowa Wesleyan University claimed that this would not be in keeping with the intention of the donors to the fund. Both parties appointed committees and legal counsel.

Protracted negotiations over this matter continued through the academic year, 1908-1909, finally ending in a stalemate. The question was submitted to a tribunal of three Methodist bishops: John W. Walden, Cincinnati; William F. Anderson, Chattanooga; and John L. Nuelson, Omaha. Their decision, August 11, 1909, to divide the endowment fund- $\$ 15,000$ to Iowa Wesleyan and $\$ 15,000$ to Central Wesleyan-was accepted.

The final day of the old German College was marked by certain unhappy experiences. Many students decided against moving to Central Wesleyan, and remained in Mt. Pleasant to attend Iowa Wesleyan University.

The most active student organization, the Goethe So- 
ciety, disbanded and re-incorporated itself as an organization of Iowa Wesleyan University under the dynamic leadership of its president, Gotthilf Carl Hueftle. For the sum of one dollar it then sold its two pianos and the furnishings of its meeting room to itself as a newly constituted organization. Trustees in irritation decided to withhold Mr. Hueftle's diploma.

Seventeen of thirty graduating students refused to attend graduation exercises or to accept their diplomas. They included two of three senior commencement speakers. Only a handful of persons were on hand in the college Chapel for the final ceremonies June 9, 1909. The remainder of the student body, audience and townspeople milled around on the lawn outside while the Board of Trustees of the German College held a hasty meeting in the main building.

President Leist, with great control and dignity, held the rather pathetic exercises minus speakers, trustees, 17 graduates and all but a few visitors. The trustees finally decided to award the diploma in question, and thereupon left town as speedily as possible. President Leist personally delivered the diplomas to the graduates in the afternoon.

The Mt. Pleasant newspapers, the Iowa Wesleyan University student paper and the 1910 Croaker, described these tragic-comic events in colorful detail. All paid tribute to President Leist for his patience, forbearance and dignity during that last year and especially on June 9 th.

Thus ended a 36-year German experiment in higher education in Iowa. Iowa Wesleyan acquired some additional buildings, half the endowment, and increased student enrollment, besides appointing former President Leist to its faculty where he served as both professor and dean until 1936. Ironically the next year Gotthilf Carl Hueftle became a teacher of mathematics in the preparatory department of Iowa Wesleyan.

The German College building was at once turned over to the university's Conservatory of Music under the 
direction of Dr. A. Rommel. The German Methodist congregation declined, and the German Chapel was also turned over to Iowa Wesleyan.

The year 1914 ushered in the violent anti-German hysteria of World War I. Iowa Wesleyan discontinued instruction in the German language, and the long tradition of Germanic studies evaporated. The school buildings were taken over by the Student Army Training Corps during World War I. The German College served as a barracks, and the German Chapel became a mess hall.

College alumni and former students placed a stone memorial tablet over the main entrance in 1910. It read: "This building was formerly the German College of Mt. Pleasant, Ia. It was united with the Central Wesleyan College of Warrenton, Mo., in 1909. This memorial tablet was erected by the German alumni and ex-students in 1910." Emotionalism ran so high during the war that the words "German College" and "German" before "alumni" were carefully chiseled out. The defaced memorial so remains to this day. The German Chapel was torn down in the 1920's, and the German College now houses the Iowa Wesleyan departments of music and physics.

The amalgamated college at Warrenton, Missouri, was not entirely successful. World War I discrimination increased its problems. The entire St. Louis German Conference was dissolved in 1924, and its churches absorbed into English Methodist Conferences.

German Methodism in Iowa came to an end in the face of wartime anti-German prejudices, and more importantly, because it failed to appeal to the second generation. Southeastern Iowa, thus, lost a distinctive and valuable people who had endeavored to preserve something of their old world culture in America.

\section{BIBILIOGRAPHY}

1. Edgar Rubey Harlan, A Narrative History of the People of Iowa. American Historical Society. Chicago. 1931 II

2. William J. Petersen, The Story of Iowa. Lewis Historical Publishing Company. New York. 1931 II 
3. William J. Petersen, Iowa History Reference Guide. State Historical Society of Iowa. Iowa City. 1952

4. The History of Henry County, lowa. Western Historical Society. Chicago. 1879

5. Historical Sketch and Alumni Record of Iowa Wesleyan University. Mt. Pleasant. 1905

6. Historical Sketch and Alumni Record of Iowa Wesleyan College. Mt. Pleasant. 1917

7. Charles J. Kennedy, History and Alumni Record of Iowa Wesleyan College. 1842-1942. Mt. Pleasant. 1942

8. Katalog des Deutschen Kollegiums. 1873-1880. Mt. Pleasant

9. Catalogs of Iowa Wesleyan University, 1873-1910

10. E. C. Magaret, Friedrich Mung and George B. Addicks, Jubilaumsbuch der St. Louis Deutschen Konferenz. Jennings and Graham. Cincinnati. 1905

11. Mt. Pleasant Weekly News. 1908-1909

12. The Croaker of Iowa Wesleyan University, 1906, 1909, 1910

13. St. Louis German Conference 1879-1925. St. Louis 1925

14. St. Louis German Conference. Official Minutes. 1924

\section{First Threshing Machine in Woodbury County}

FROM SMITHLAND.-Last Monday a threshing machine arrived at the farm of O. B. Smith, and commenced threshing, being the first work of the kind in Woodbury County. O. B.'s farm was the first that raised wheat in the County, and the first to have a machine on it. - The farm was worked this season by Abel Smith and James Moon, and they raised over six hundred bushels of small grain-wheat, oats and rye. The rye yielded 35 bushels to the acre; oats 45 ; wheat 21 . We hailed the arrival of the machine with joy. The Smithland boys got up a dance, and things went off after the old sort down East. The machine is from Davenport, and belongs to $\mathrm{Mr}$. Treps, a brother-in-law of Benj. Stafford of the Floyd. It is an excellent one.

November 29, 1859.-Sioux City Register, December 3, 1959. 
Copyright of Annals of Iowa is the property of State of Iowa, by \& through the State Historical Society of Iowa and its content may not be copied or emailed to multiple sites or posted to a listserv without the copyright holder's express written permission. However, users may print, download, or email articles for individual use. 